\title{
Economic Disparity in Coastal Area of Bengkulu Province
}

\author{
Nola Windirah*, Muhamad Mustopa Romdhon, Satria Putra Utama, Reflis \\ Agribusiness Department, Agriculture Faculty, University of Bengkulu, Indonesia
}

\begin{abstract}
The issue of economic disparity is still a major issue in development in the coastal areas of Bengkulu Province. The region's high economic growth $(5.35 \%)$ was eroded by the high rate of inflation $(5 \%)$, the economy grew only $0.14-1.12 \%$. The question is whether the decreasing of Bengkulu Province's economic growth due to inflation has contributed to regional economic disparity, on the coastal of Bengkulu Province specifically? The data analysis method used to assess the level of economic disparity is the Williamson Index. The results indicated that the economic growth (Gross Regional Domestic Product - GRP) in coastal areas was higher than in non-coastal areas. Economic disparities between coastal and non-coastal areas in Bengkulu Province for the 2011-2019 period widened, disparity in coastal areas was bigger than in non-coastal areas.
\end{abstract}

Keywords: coastal disparity, economy growth, non-coastal

Received 14 September 2020 | Revised 3 October 2020 | Accepted 9 November 2020

\section{Introduction}

Economic disparity is still a major issue in coastal development in Bengkulu Province. There are six districts on the coastal area in Bengkulu Province. In 2016, the economic growth of Bengkulu Province on average was $5.23 \%$ higher than the national economic growth of $5.02 \%$ and the provinces in Sumatra Island were 4.50\%. In 2011 to 2019, The average district economic growth also shows the same trend in the coastal districts such as South Bengkulu (5.57\%), Seluma (5.31\%), Mukomuko (5.64\%), Kaur (5.19\%), and Bengkulu City (6.10\%) as well as in non-coastal districts such as Kepahiang District (5.69), Rejang Lebong (5.55\%) and Lebong (5.24\%). However, the high rate of inflation (5\%) caused economic growth to be decreased so that it only grew by 0.19 $1.10 \%$.

High economic growth (GRP) is determined by factors of technology, labor, capital, population growth, human resources and natural resources [1, 2]. Disparity in economic growth between regions is determined by economic concentration, mobility of goods, public and private investment as well as natural resources, human and cultural resources $[3,4,5,6,7]$. The accumulation of these components will accelerate the economic growth of a region or country or vice versa.

\footnotetext{
*Corresponding author at: Agribusiness Department, Faculty of Agriculture, Universitas Bengkulu, Jl. WR. Supratman, Kandang Limun, Bengkulu, Indonesia

E-mail address: nolawindirah@unib.ac.id
} 
In coastal areas, geographically remote and difficult accessibility so that the economic reach is limited, and the availability of basic infrastructure is not optimal or has not been built such as roads, education and health. Causing the mobilization of economic resources is very limited compared to non-coastal areas. This is shown by the percentage of people life in poverty in Bengkulu Province in 2016 which reached $17.03 \%$ [8], this poverty rate is higher than the percentage of national poverty and Sumatra Island, respectively $10.70 \%$ and $10.50 \%$. The question is whether the decreasing of economic growth will further encourage disparity in the coastal economy of Bengkulu Province so that the poverty rate is getting higher.

\section{Methods}

This research was conducted in Bengkulu Province in nine districts six coastal districts (Kaur, Seluma, South Bengkulu, Bengkulu Tengah, Bengkulu Utara and Mukomuko) and three noncoastal districts (Rejang Lebong, Lebong and Kepahiang). Data were collected using documentation methods including data on GRP, GRP per capita, and economic dan population growths. The data comes from Bengkulu in Figures, from 2011 to 2019. Economic growth is calculated as a percentage, while the method for measuring regional economic disparity is the Williamson index (Williamson, 1965). The size of the gap is based on the coefficient of variation (CV), namely the standard deviation divided by the average with the formula:

$$
\mathrm{CV}_{\mathrm{w}}=\frac{\sqrt{\sum_{i}\left(\bar{Y}_{i}-\bar{Y}\right) \frac{n_{i}}{n}}}{\bar{Y}}
$$

where : $\mathrm{CV}_{\mathrm{w}}=$ weighted coefficient of variation; $\mathrm{n}_{\mathrm{i}}=$ Population in district $\mathrm{i} ; \mathrm{n}=$ total number of the population; $\overline{y_{l}}=$ per capita income in district I; $\bar{y}=$ average income per capita of all districts (Province)

\section{Results and Discussion}

\subsection{Coastal and Non-Coastal Economic Growth}

The economic growth of Bengkulu Province is divided into coastal areas, namely Seluma, South Bengkulu, Kaur, North Bengkulu, Central Bengkulu, Mukomuko districts and Bengkulu City. Non-coastal districts namely Rejang Lebong, Kepahiang, and Lebong Districts. Economic growth in the three non-coastal areas in Bengkulu Province during the period 2011 - 2019 ranged from 4.97 to 6.52 (see Figure 1). 


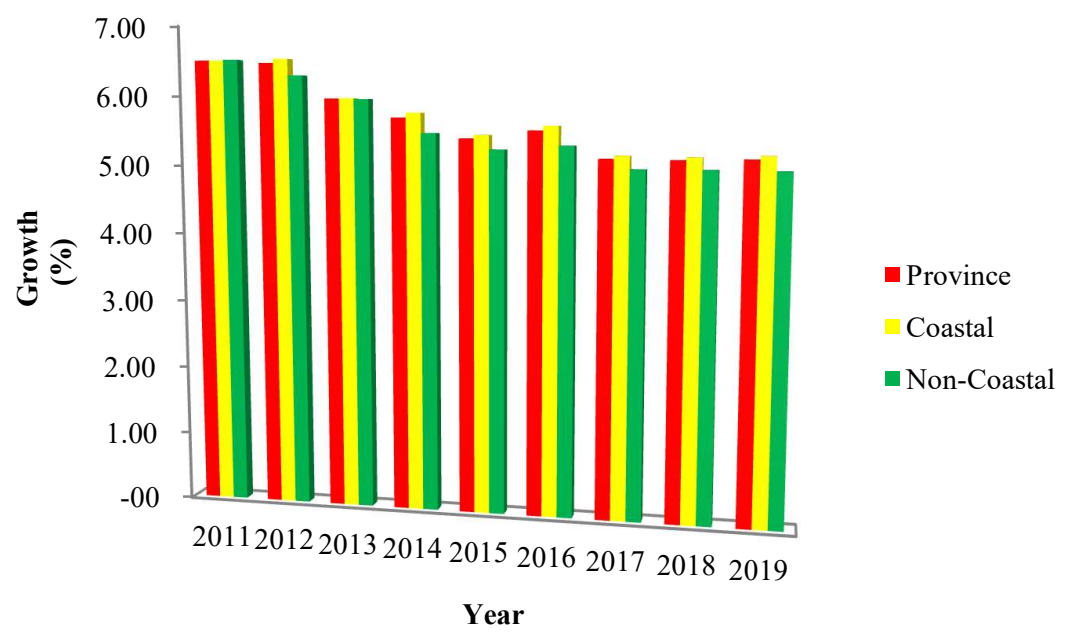

Figure 1. Coastal and Non-Coastal Economic Growth in Bengkulu Province, 2011-20119

The results indicated that the economic growth (Gross Regional Domestic Product - GRP) in coastal areas was higher than in non-coastal areas. Per capita income in Bengkulu Province, both coastal and non-coastal areas, shows an increasing trend in line with economic growth, this is indicated by an increase in GRP. The per capita income of people living in coastal areas ranges from Rp.1.39 million - Rp.1.82 million. This income was not different with the per capita income of people in non-coastal areas, which ranges from Rp.1.23 million - Rp.1.71 million (see Figure 2). The most common condition facing by non-coastal districts in Bengkulu was geographically remote and difficult accessibility so that the economic reach is limited, and the availability of basic infrastructure is not optimal or has not been built such as roads, break out bridge. While coastal districts except Bengkulu City and the availability of basic infrastructure is not optimal or has not been built such as seaports, airport and limited public transportation services among islands to main islands such Tikus, Enggano, Mega Islands and others.

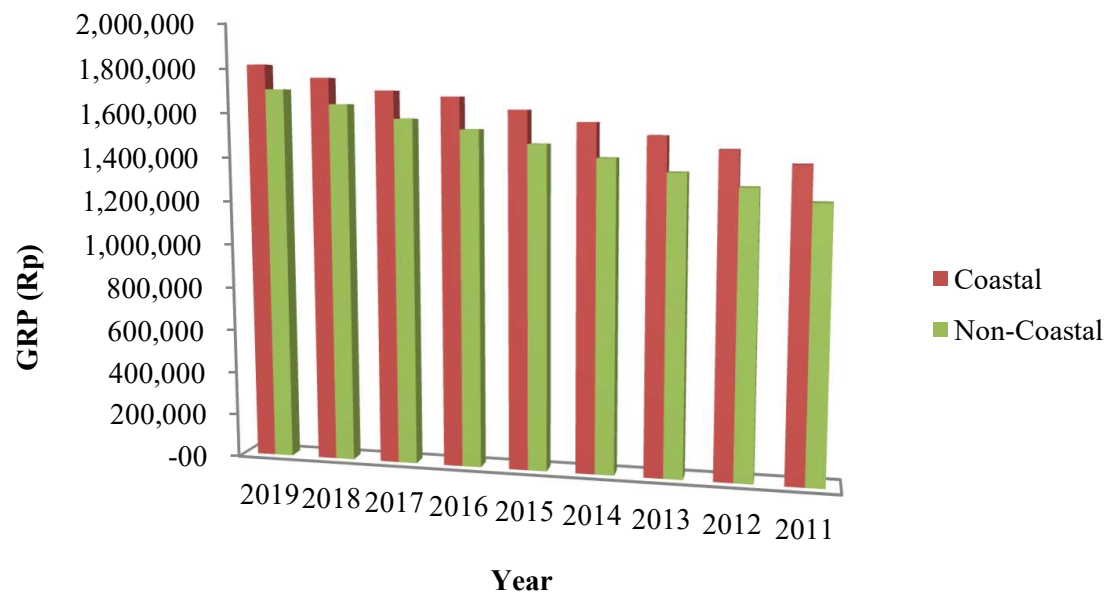

Figure 2. Per Capita Income of Coastal and Non-Coastal Communities in Bengkulu Province, 2011-2019 


\subsection{Economic Disparity for Coastal and Non-Coastal Areas}

The growth in per capita income during the period 2011 - 2019 on the Non-Coastal tended to increase, compared to the growth in per capita income in coastal areas which was relatively more stable. The economic sector, such as trade in services and processing industries, which support the economy of this region, is growing steadily compared to the coastal economic sector which is supported by agriculture, especially oil palm plantations and fisheries. Wide economic disparity occurs in Bengkulu Province, both on the coastal and in the non-coastal. This is indicated by the Williamson Index getting closer to one, namely 0.45 . Figure 3 showed that there is increasing trend of inequality in Bengkulu Province specially on non-coastal. Wahyuningsih [9] also showed that inequality exist in the Bengkulu Province. Disparity in coastal and non-coastal areas with the Williamson index of 0.45 and 0.06 , respectively. Economic disparity in coastal areas is relatively higher than economic disparity in non-coastal areas during the period 2011-2019 (see Figure 3). Its show that the level of inequality between areas were high, as found by [10] this imbalances was significant effect of population growth and investment. Investment such as services, hotel and trade were the most significant contribution to GRP of coastal economic.

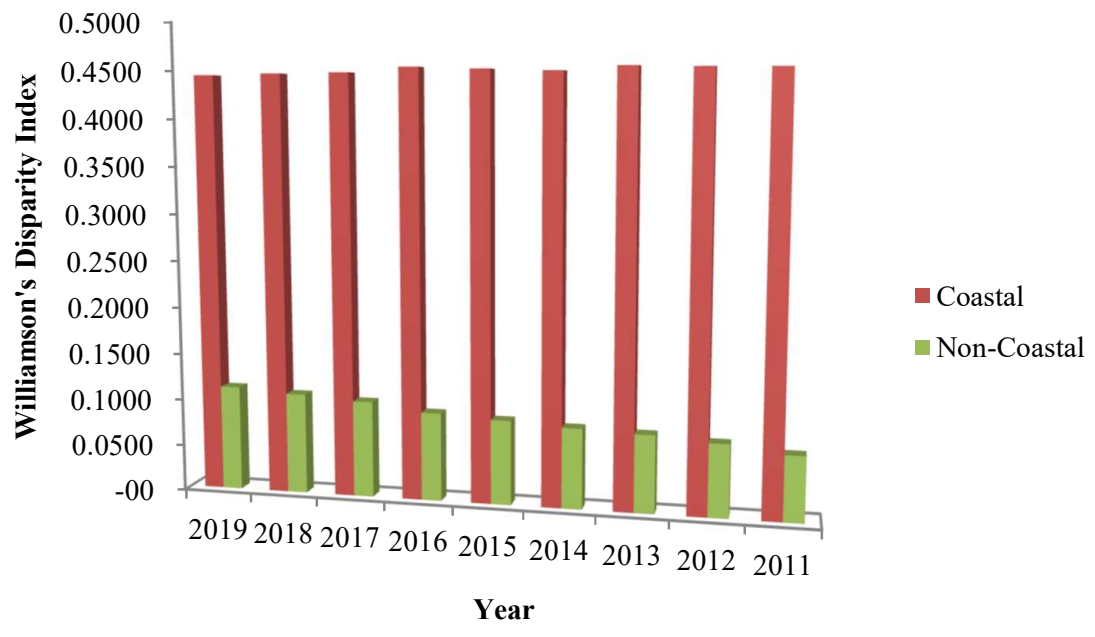

Figure 3. Williamson's Disparity Index at Coastal and Non-Coastal in Bengkulu Province, 2011-2019

The results of this study indicate that economic disparity has widened between coastal and noncoastal areas in Bengkulu Province for the 2011-2019 period. Arianti [11] also shows that economic disparity between coastal areas has increased since the division of the region. This imbalance is caused by several factors, including:

1) The economic concentration in the two regions is relatively different. As said by $[3,4,5,6$, 7] that the disparity in economic growth between regions is determined by economic 
concentration, mobility of goods, public and private investment as well as natural resources, human and cultural resources. The non-coastal economy has experienced a shift in economic activity from the agricultural sector to the secondary sector such as processing, trade and services, tourism such as in Rejang Lebong and Lebong Districts. The economic concentration of the agricultural sub-sector is on vegetables and horticulture, such as in Kepahiang and Rejang Lebong districts. The economic concentration on the coast is more uniform and dominant in the primary agricultural sector such as capture fisheries and oil palm plantations,

2) The mobility of production factors and goods experiences constraints due to hilly geographical conditions and is in highlands such as non-coastal areas. While damage constraints and limited infrastructure roads and ports as on the coastal. Both condition lead to the transportation costs of production and production inputs are expensive.

3) Investment is still dominated by regional government public spending, where the source of development capital still relies on the central government through the General Allocation Fund (DAU) and the Special Allocation Fund (DAK) so that the acceleration and distribution of economic development limited despite high economic growth. The quality of government spending (government spending) is relatively low, where the ratio of capital expenditure (investment and public services) is lower than expenditure routine (administration and employee salaries), and

4) The abundance of natural resources differs between coastal and non-coastal areas which is one of the reasons for the differences economic concentration, but there is no difference in the level of quality of human resources and culture.

\section{Conclusion}

GRP growth in coastal areas is higher than in non-coastal areas although per capita income of both shows an increasing trend. Economic disparities between coastal and non-coastal areas in Bengkulu Province for the 201-2019 period widened, where the disparity of coastal higher than non-coastal. By increasing government spending on productive expenditures such as develop mass public transportation infrastructure (toll road, trains and seaports) and connecting road among production to market center would be decreased disparity.

\section{REFERENCES}

[1] M. P. Todaro and S. C. Smith, Economic Development (the 11th edition). Boston: Pearson Addison Wesley, 2012.

[2] N. G. Mankiw, E. Quah, and P. Wilson, Introduction to Macroeconomics: Asian Edition. Jakarta: Salemba Empat. 2014.

[3] A. A. Muthalib, "Analysis of economic growth and development gaps between cities in Southeast Sulawesi," International Journal of Economic and Financial Issues, vol. 7, no. 2, 
pp. 125-128, 2017.

[4] I. J. Azis, Ilmu Ekonomi Regional dan Aplikasinya di Indonesia. Jakarta: LPFE UI, 1994.

[5] H. Esmara, Perencanaan Pembangunan. Pusat Antar Universitas. Jakarta: FE UI. 1996.

[6] Daryanto and Hafrizianda, Model-Model Kuantitatif Konsep dan Aplikasi. Bogor: IPB Press. 2010.

[7] Rustiadi, dkk. Perencanaan dan Pengembangan Wilayah. Jakarta: Crespent Press dan Yayasan Obor Indonesia, 2011.

[8] Badan Pusat Statistik, Data Sosial Ekonomi Strategis. Jakarta: Badan Pusat Statistik. 2017.

[9] T. Wahyuningsih, M. Bugis, and S. Z. Bin-Tahir, "Analysis of inequality on inter-regional and inter-time income distribution in Indonesia," The Journal of Social Science Research, vol. 5, no. 1, pp. 1 -8. 2019.

[10] Barika, "Analisis Ketimpangan Wilayah Kabupaten/Kota di Provinsi Bengkulu Tahun 2005 - 2009," Jurnal Ekonomi dan Perencanaan Pembangunan, vol. 4, no. 3, pp. 1- 11, 2017.

[11] N. N. Arianti and I. Cahyadinata, "Kajian dampak pemekaran wilayah terhadap Kesenjangan Ekonomi Antar Pesisir di Provinsi Bengkulu," Jurnal Agrisep, vol. 15, no. 1, pp. 27-36. 2016. 